\title{
Diabetes education in Mexico: patient and family
}

\section{Educación sobre diabetes en México: paciente y familia}

\author{
Aldo Pelcastre-Neri ${ }^{a}$, Vanessa C. de Carranza-Ayala ${ }^{b}$
}

\begin{abstract}
:
Introduction. Despite the efforts to provide care for people with type 2 diabetes by conducting multiple intervention studies to educate people with diabetes mellitus, work still needs to be done to include the family as a strategy to improve disease control. Objective. A systematical review was made with the objective of analyzing educational interventions, implemented in adult people with diabetes mellitus type 2 in Mexico, including their family. Materials and Methods. Bibliographic search was made in CrossRef, Medline (PubMed), EBSCO, SCIELO and UAEH digital library. Results. From the nine articles found, seven mention the importance of the family receiving diabetes education. However, none of them mention the family in educational sessions as part of comprehensive management. Three articles mention the economic impact to the family as an out-of-pocket expense. Conclusions. Educational interventions in diabetes significantly improve the metabolic control of people with diabetes mellitus type 2, however, in Mexico there is no evidence of the inclusion of the family in such interventions, whose importance lies as support within the family system.
\end{abstract}

\section{Keywords:}

Education, diabetes type 2, Mexico, intervention, family

\section{Resumen:}

Introducción. A pesar de los esfuerzos que existen para brindar atención a las personas con diabetes tipo 2 realizando múltiples estudios de intervención para educara personas con diabetes mellitus, aún se necesita trabajar para incluir la participación de la familia como estrategia para mejorar el control de la enfermedad. Objetivo. Mediante una revisión sistemática analizar intervenciones educativas aplicad as a personas adultas con diabetes mellitus tipo 2 realizadas en México y el grado de participación de los familiares. Material y métodos. La búsqueda bibliográfica se realizó en las bases CrossRef, Medline (PubMed), EBSCO, SCIELO y biblioteca digital UAEH. Resultados. De los nueve artículos encontrados, siete mencionan la importancia de que la familia reciba educación en diabetes. Sin embargo, ninguno menciona incluir a la familia en las sesiones educativas como parte del manejo integral. Tres artículos mencionan el impacto económico a la familia como gasto de bolsillo. Conclusiones. Las intervenciones educativas en diabetes mejoran significativamente el control metabólico de las personas que padecen diabetes mellitus tipo 2. En México no se ha encontrado evidencia de incluir a la familia en dichas intervenciones, cuya importancia radica como apoyo dentro del sistema familiar.

\section{Palabras Clave:}

Educación, diabetes tipo 2, México, intervención, familia

\section{INTRODUCTION}

Currently, low to high-income countries have focused their interest in public policies to improve public health's status on population, to face the consequences of diverse diseases, mainly, confronting daily incidences from many illnesses. Chronic degenerative diseases are the most, like diabetes mellitus, arterial hypertension and cardiovascular diseases, but they could be avoided; nevertheless, people with this kind of illness increases. ${ }^{1}$ Mexico is not an exception. It has been tried to find a solution that contributes with a health improvement, especially for diabetes mellitus. Mexico is trying to decrease diabetes mellitus incidence, improving life styles promoting the healthy ones, besides, it includes the whole family for therapies, because education is an indispensable pillar for a successful glucose and metabolic control of people with diabetes mellitus. ${ }^{2,3}$

Both patients and family members share risk factors, which demand pertinent attention to prevent disease and condition derived from unhealthy life styles. Health and educational

\footnotetext{
a Corresponding autor, Consultorio privado, Pachuca, Hgo., https://orcid.org/0000-0002-7159-2969, Email: life_9422@ hotmail.com b Consultorio Privado, Pachuca, Hgo., Email: vcaballerocarranza@gmail.com
} 
institutions have been developing strategies during at least 10 years, but practical implementation has not been possible. It is an opportunity area that contributes to metabolic control in people with diabetes mellitus. ${ }^{2}$

Efforts in public policies in Mexico are well sustained. Its continuity and position make possible their implementation and verification, contributing to health prevention and promotion in population. ${ }^{4}$ Some policies, for example, sugary drinks taxes, mandatory frontal labelling, censoring publicity with high calorie content during kids viewing time, outstand from others because are in fact implemented and valued, so population may know them and support them. In contrast, main objectives are far away, because prevalence and score in diabetes mellitus, within its complications are not decreasing, causing mortality. ${ }^{5-9}$

According to the International Diabetes Federation (IDF), prevalence of persons with diabetes disease in 2017 were 425 million all around the world. Ages oscillate between 20 and 79 years old. From that, $79 \%$ are people living into low-middle income countries. If age category increases from 18 to 99 years old, the number of populations will be 451 million. If that rate remains, then 629 million people from 20 to 79 years old and 693 million people from 18 to 99 years old will have diabetes in 2045. ${ }^{9}$ In concrete, economic dynamic in some countries from low to middle incomes will cause more population with diabetes.

Estimations have rated alarming increases during many decades. So, more than a third part of the population with diabetes are caused by growing and aging: $28 \%$ increased by age prevalence, while $32 \%$ is due to an interaction between growing and aging. ${ }^{9}$ In the same way, the cause of the expensive costs and economic burden on health is closely related to the degree of metabolic control. In Latin America, it is estimated that a $70 \%$ from population with diabetes have an improper control. ${ }^{10}$

In 2015, The World Health Organization (WHO) determined that diabetes mellitus caused 1.6 million death people around the world. Furthermore, hyperglycemic states provoked 2.2 million deaths. Even more, WHO projected that in 2030 diabetes will be the 7 th cause of mortality around the world..$^{11}$

According to the data of FID (2017), Mexico occupies the fifth place with diabetes mellitus population in the world, with 12 million. ${ }^{9}$ In addition, people with diabetes rises from $9.2 \%$ in 2012 to $9.4 \%$ in 2016 in Mexico. Men between 60 to 69 years old and women older than 60 . Also, there is a report of a $10.2 \%$ prevalence of people with medical diagnosis in south region. Women had the highest prevalence in the center of the country with $11.7 \%$, and men in the southern region with $11.2 \%{ }^{6}$

Two-year Health at a Glance report (2017) rates Mexico in first place of diabetes in the Organization for Economic Cooperation and Development (OECD). Its prevalence is $15.8 \%$ in population between 20 to 79 years old. As a consequence, Mexico has doubled the prevalence in diabetes mellitus compared to other OECD countries, when average is $7 \%$ for members. Due to this, there is a mortality alert in contrast with Estonia, Ireland, Luxemburg, Sweden and The United Kingdom, where only $5 \%$ of adult population have that disease. ${ }^{5,6}$

According to Official Mexican Standard NOM-15 for prevention, treatment and diabetes control, $8.2 \%$ of population between 20 and 90 years old have diabetes; in addition, $30 \%$ do not know they have a disease. So, it is estimated that Mexico have more than four million people with diabetes mellitus, but more than a million have not been diagnosticated yet. ${ }^{12}$

Many studies have demonstrated benefits about diabetes education to improve metabolic control in people. It improves knowledge, decision making and decreases healthcare costs caused by disease. ${ }^{3,13,14}$ Thus, including family members, many researches have related family role and types of family with glycemic control. Family support impacts in diabetes control, also in knowledge about disease and contributes with making decisions. ${ }^{8,14-23}$

Alulima Salazar ${ }^{18}$ mentioned that deficient family support in most patients with diabetes causes regular adherence to treatment. Most of patients with diabetes mellitus disease do not get family support, because family do not know their influence on sick people`s well-being, causing unhealthy conditions into integral health. Besides, family information determinates support in patient with diabetes mellitus, due to its influence into metabolic control. ${ }^{17}$ As it can be seen above, it is important to educate first degree relatives in cohabitation with a person with diabetes mellitus, so they can intervene indirectly with their therapy and reach favorable results for all. ${ }^{12}$

Perez Rodríguez et al. ${ }^{17}$ mentioned that both patient and family conform a risk group. That is to say that training of all is important to prevent disease, through health life styles. In addition, therapeutic education for both should be progressive and continuous, with the objective of actively involve both of them as part of the therapy.

Due to this, this study has the objective of analysing educational interventions, implemented into adult people with diabetes mellitus type 2 in Mexico, including family.

\section{MATERIALS AND METHODS}

Bibliographic search was made in CrossRef, Medline (PubMed), EBSCO, SCIELO and UAEH digital library and articles between 2010 and 2018 were considered. Using keywords as 
"education", "diabetes type 2", "Mexico", "intervention" and "family". At first, 25 papers were found. Population was used as a filter (studies with adults), language (English and Spanish), and country (Mexico), and 18 papers were obtained. Through reading and reviewing, only 9 researches were selected, excluding those without an intervention study in people with diabetes mellitus type 2 .

\section{RESULTS}

After a process of information search and selection, 9 papers were included (Figure 1). Main characters and results are resumed in Table 1.

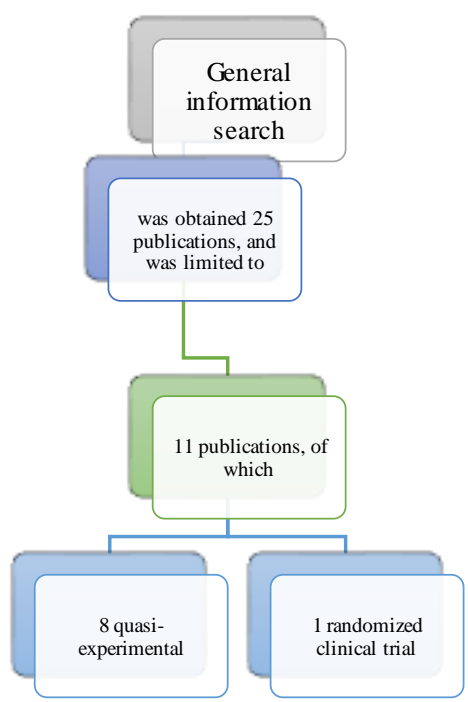

Figure 1. Strategy for publications selection (own elaboration).

\section{Intervention studies}

Diabetes mellitus is a disease which requires many therapies. This is why it is a complex disease. Mexico has made some efforts facing problems about education of people with diabetes mellitus, however, a lack of publications about educational intervention was identified, as it was expected.

Diverse ways of leading with human behavior of people with diabetes mellitus have been proposed. They have as a goal to improve metabolic control, for a better life quality. In the Hernandez Lira ${ }^{24}$ study, a randomized clinic trial made an assessment of the effectiveness on a medical therapy within diabetes education, through an educational multimedia tool, in comparison with a habitual medical care. Two hundred and forty six patients with diabetes mellitus type 2 were part of the research, but there were not statistically significant differences into BMI, diabetes knowledge, blood pressure, self-efficacy, self-informed medical care; on the other hand, perceived susceptibility of complications showed significant statistical differences.

All quasi experimental researches have had favorable results in different variables that were considered. Differences between them were related to population to which the project is directed, social demographic and cultural characteristics, members leading intervention (either multidisciplinary or not) and gender differences.

In the research by Ávila Domínguez ${ }^{25}, 28$ indigenous people with diabetes mellitus type 2 were educated during 8 weekly sessions, and no significative differences on weight were founded; on the other hand, waist circumference was statistically relevant $(\mathrm{p}=0.00)$, systolic blood pressure $(\mathrm{p}=0.00)$, and glycosylated hemoglobin $(\mathrm{p}=0.00)$. In addition to it, Hernández Sánchez ${ }^{26}$ studio evaluated results of a year training for 449 people with diabetes mellitus Type 2 inside a group called DiabetIMSS, showing an increase of controlled patients in variables as fasting glucose, glycosylated hemoglobin, total cholesterol, triglycerides and blood pressure.

Mexico gives specialized attention through Medical Specialties of Critical Diseases Units (UNEME-EC). UNEME are able to give integral attention to people with diabetes mellitus, as an example. Velasco Limón`s ${ }^{27}$ study included an educational program with 83 patients with diabetes mellitus type 2 inside a UNEME-EC. The educational program worked during 6 educational sessions and 8 weekly workshops or dynamics of learning. The results showed that people increased their knowledge level about diabetes mellitus, statistical significant with $\mathrm{p}<0.0011$, besides biochemical data with $\mathrm{p}<0.05$ on blood pressure, waist circumference, capillary glycaemia, glycoside hemoglobin, total cholesterol in women, meanwhile for men only capillary glycaemia and glycoside hemoglobin.

Evidently, there is a clear result difference, because women had more statistically significant variables in comparison with men. It is an important data to be considered in subsequent studies and find strategies for an improvement of the same data in men.

Likewise, a study made by Hernández et al. ${ }^{28}$ implemented 16 workshops with weekly sessions. In this study, diabetes education is part of a therapy and showed an improvement in the knowled ge level, statistically significant $\mathrm{p}=0,00$ of people with diabetes mellitus type 2 , and glycosylated hemoglobin results report a lack of significant differences.

Conforming a multidisciplinary team for educational interventions demonstrate the importance of integral attention in health care services in Mexico. The study by Pichardo Hernández et al. ${ }^{29}$ reinforces the aforementioned. They had 6 sessions of two hours per week, with a multidisciplinary team in charge (Family medicine, Nutrition, Stomatology, Social Work, etc.), where the number of participants with an adequate level of knowledge and glycemic indexes for a disease control, improved. At the end, authors concluded about the importance of increasing human and financial resources, so results could even get better, because main limitations were related to economic resources requirements for transportation and the lack of support from the family. 
Guzmán Priego et al. ${ }^{30}$ implemented monthly chats for 25 people with diabetes mellitus type 2 . They provided the users with an information kit about diabetes mellitus type 2 for therapy and prevention. At the end, the people's average blood glucose were reduced, as well as glycosylated hemoglobin, creatinine, urea, BUN, cholesterol and triglycerides. Besides, results were statistically significant on glucose $\mathrm{p}=0.0127$, glycosylated hemoglobin $\mathrm{p}=0.0045$, cholesterol $\mathrm{p}=0.0025$ and triglycerides $\mathrm{p}=0.0114$. Finally, they concluded that diabetes education influenced directly on changes in biochemical data that were part of their research.

The diversity of methods to manage the intervention are noticeable. For instance, the study from Velasco Casillas et al. ${ }^{31}$ only had one two-hour session. Thirty adult patients diagnosticated with diabetes mellitus type 2 were part of it, inside a Health Center dependent of the Ministry of Health. During the only session an intervention occurred, and conversational maps were used; at the end, participants were equipped with didactic materials as a complement. Pre and post measurement were implemented with a rank of three months of difference between them. Implemented measurement were about diabetes knowledge, clinical measures, anthropometrics and biochemical ones. Results were statistically significant for glucose $(p=0.017)$, diastolic blood pressure average $(p=0.009)$ and knowledge level ( $\mathrm{p}=0.001)$; in contrast, BMI, glycosylated hemoglobin, triglycerides and total cholesterol.

Vargas Ibáñez et at. ${ }^{14}$ also made a study in patients diagnosed with diabetes mellitus type 2 , at the end of a year for people with diabetes. The intervention consisted in 12 two-hour weekly sessions each for the experimental group. The main topic was about "diabetes education, decreasing ignorance costs". From Andalusia Regional Government Health Council, a control group was part of traditional education about self-care and disease therapy during their scheduled appointments. The intervention`s duration was the same as the intervention for the experimental group. Three measurements were made: one before intervention, another one after 6 months, and the last one a year later. Results showed statistically significant differences in the study group, in variables like serum glucose $\mathrm{p}=0.004$, quality of life with $\mathrm{p}=0.01$ and knowled ges $\mathrm{p}=0.00$; in contrast, the control group did not show relevant data. Total cholesterol and triglycerides did not show significant data, neither did the control and study groups. The quality of life got worse from the second to third measurement. According to the author, it was a consequence of a lack of follow-up on behalf of the health team. As a consequence, there was a lack of interest by sick people on their life quality.

\section{Family inclusion}

From a total of papers, only seven mentioned the importance of the family's education about diabetes. None of them mentioned the inclusion of the family in educational sessions of patients as part of an integral management. Three articles only mentioned economic impact for the family as an out of pocket spending caused by the disease.

The participation of family members in the patients' therapy is critical. ${ }^{32}$ After a detailed review, all researches that included educational intervention were implemented only for patients with diabetes mellitus. Nevertheless, researches show a theoretical evidence about the importance of such implementation for family members. For example, Hernández Sánche $z^{26}$ mentioned that DiabetIMSS program had as a main objective to achieve positive behaviors and changes in the life style of patients along with their family. In the same way, the study of Guzmán Priego et al. ${ }^{30}$ mentioned the importance of diabetes education. To them, the importance is focused on being informed, motivated and also in the strength of people with diabetes and their family members; in addition, they said that positive changes in quality of life depended on patients, health staff and their family members. However, the educational importance ${ }^{33}$ was an essential part of health planning and must involve the patient's family, the diabetes care team, the community and all the decision makers during the educational process. ${ }^{14,34,36}$ Besides, they add recommendations from the American Diabetes Association (ADA) focused on the objective of early education for the sick person and his/her family to selfmanage the disease. ${ }^{35}$

\section{DISCUSSION}

None of the papers that were reviewed included the educational intervention for the family of people with diabetes mellitus type 2. Nevertheless, seven of the nine researches considered the importance of family role in the disease control, even though they included a fundament inside a theoretical framework.

Each research favored the patients in some aspect. All of this contributes to a favorable state of health. Educational interventions in Mexico were favored by collaborative work between different health disciplines. Some of them made a diagnostic before the intervention and planned appropriate strategies for the study population. As a consequence, the probability of success increases. 
Table 1. Studies summary

\begin{tabular}{|c|c|c|c|c|c|c|}
\hline $\begin{array}{l}\text { Author } \\
\text { and year }\end{array}$ & Paper's name & Aim & Type of design & Sample & Main results & $\begin{array}{l}\text { Inclusion of } \\
\text { family } \\
\text { members in } \\
\text { the } \\
\text { intervention }\end{array}$ \\
\hline $\begin{array}{c}\text { Ávila } R, \\
2018^{25}\end{array}$ & $\begin{array}{l}\text { Education on diabetes } \\
\text { from an intercultural } \\
\text { focus since Cognitive } \\
\text { modifiability theory - } \\
\text { Instrumental } \\
\text { Enrichment Program } \\
\text { [FIE]. }\end{array}$ & $\begin{array}{l}\text { To evaluate the effect } \\
\text { of diabetes education } \\
\text { with an intercultural } \\
\text { approach based on the } \\
\text { Theory of Cognitive } \\
\text { Modifiability- } \\
\text { Instrumental } \\
\text { Enrichment Program } \\
\text { [PEI] on the } \\
\text { anthropometric } \\
\text { measures, serum } \\
\text { glucose and } \\
\text { glycosylated } \\
\text { haemoglobin levels of } \\
\text { the participants. }\end{array}$ & $\begin{array}{l}\text { Quasi- } \\
\text { experimental }\end{array}$ & $\begin{array}{lr}28 & \text { adult } \\
\text { persons } & \text { with } \\
\text { diabetes } & \\
\text { mellitus } & \end{array}$ & $\begin{array}{l}\text { Differences in waist } \\
\text { circumference } \\
(\mathrm{p}=0.00), \quad \text { systolic } \\
\text { blood pressure } \\
(\mathrm{p}=0.00) \text { and glycated } \\
\text { hemoglobin }(\mathrm{p}=0.00) .\end{array}$ & Not included \\
\hline $\begin{array}{l}\text { Hernández, } \\
N, 2018^{26}\end{array}$ & $\begin{array}{l}\text { Effectiveness of } \\
\text { Diabetes education on } \\
\text { Clinical and } \\
\text { biochemical parameters } \\
\text { in Diabetes Mellitus } \\
\text { Patients that have } \\
\text { concluded one year } \\
\text { training as part of } \\
\text { Diabetims group in } \\
\text { HGZ with UMF1, } \\
\text { Pachuca, Hidalgo }\end{array}$ & $\begin{array}{l}\text { To evaluate the } \\
\text { efficacy of diabetes } \\
\text { education on clinical } \\
\text { and biochemical } \\
\text { parameters in patients } \\
\text { with diabetes mellitus } \\
\text { who completed a year } \\
\text { of training in the } \\
\text { Diabetimss group at } \\
\text { HGZ with UMF 1, } \\
\text { Pachuca, Hidalgo. }\end{array}$ & $\begin{array}{l}\text { Quasi- } \\
\text { experimental } \\
\text { Observational, } \\
\text { comparative, } \\
\text { longitudinal, } \\
\text { retrospective. }\end{array}$ & $\begin{array}{l}499 \text { patients } \\
\text { with diabetes } \\
\text { mellitus }\end{array}$ & $\begin{array}{l}\text { Metabolic control as } \\
\text { achievement, from } \\
32.08 \% \text { at the } \\
\text { beginning and } 77.95 \% \\
\text { at the end. }\end{array}$ & Not included \\
\hline $\begin{array}{l}\text { Velasco E, } \\
2016^{27}\end{array}$ & $\begin{array}{l}\text { Effectiveness of an } \\
\text { educational intervention } \\
\text { in knowledge level of } \\
\text { patients with diabetes } \\
\text { mellitus type } 2 \text { of } \\
\text { Medical specialties } \\
\text { Units of Chronic } \\
\text { diseases in the Federal } \\
\text { District. }\end{array}$ & $\begin{array}{l}\text { To evaluate the } \\
\text { effectiveness of an } \\
\text { educational in } \\
\text { intervention three } \\
\text { patients aged thr } \\
\text { Units of Medical } \\
\text { Specialties for } \\
\text { Chronic Diseases } \\
\text { (UNEME-EC) of the } \\
\text { Federal District. }\end{array}$ & $\begin{array}{l}\text { Quasi- } \\
\text { experimental, } \\
\text { descriptive and } \\
\text { analytic, } \\
\text { intervention } \\
\text { type before- } \\
\text { after (pre-post) }\end{array}$ & $\begin{array}{l}83 \text { patients } \\
\text { with diabetes } \\
\text { mellitus }\end{array}$ & $\begin{array}{l}\text { Increase of knowledge } \\
\text { level }(\mathrm{p}<0.0011) \text { and } \\
\text { biochemical } \\
\text { parameters } \\
\text { statistically significant } \\
\text { in systolic and } \\
\text { diastolic blood } \\
\text { pressure, weight, } \\
\text { BMI, waist } \\
\text { circumference, } \\
\text { capillary glycaemia } \\
\text { and glycosylated } \\
\text { hemoglobin in men. }\end{array}$ & Not included \\
\hline $\begin{array}{l}\text { Hernández } \\
P, \\
\text { Maldonad } \\
o \text { G, Trejo } \\
\text { C, López } \\
\text { B, Cano A, } \\
2015^{28}\end{array}$ & $\begin{array}{l}\text { Effect of health } \\
\text { education in people with } \\
\text { type II diabetes from } \\
\text { health center of } \\
\text { Atotonilco de Tula, } \\
\text { Hidalgo, Mexico. }\end{array}$ & $\begin{array}{l}\text { To evaluate the effect } \\
\text { of a health education } \\
\text { program in patients } \\
\text { with type } 2 \text { diabetes } \\
\text { mellitus as part of non- } \\
\text { pharmacological } \\
\text { treatment. }\end{array}$ & $\begin{array}{l}\text { Quasi- } \\
\text { experimental } \\
\text { pre-post type }\end{array}$ & $\begin{array}{l}13 \text { patients } \\
\text { with diabetes } \\
\text { mellitus type } 2\end{array}$ & $\begin{array}{l}\text { Knowledge level } \\
(p=0.008)\end{array}$ & Not included \\
\hline $\begin{array}{l}\text { Pichardo } \\
J, \text { Elizaldi } \\
N, 2015^{29}\end{array}$ & $\begin{array}{l}\text { Scope of an Educational } \\
\text { Strategy in Diabetic } \\
\text { Patients of a Family } \\
\text { Medicine Unit }\end{array}$ & $\begin{array}{l}\text { To carry out a strategy } \\
\text { addressed to diabetic } \\
\text { patients to improve } \\
\text { control of their } \\
\text { disease. }\end{array}$ & $\begin{array}{l}\text { Quasi- } \\
\text { experimental } \\
\text { with } \\
\text { Educational } \\
\text { intervention, } \\
\text { with measures } \\
\text { before and after } \\
\text { research. }\end{array}$ & $\begin{array}{l}20 \text { patients } \\
\text { with diabetes } \\
\text { mellitus }\end{array}$ & $\begin{array}{l}\text { Positive modification } \\
\text { in knowledge level, } \\
\text { besides glucose } \\
\text { control improvement } \\
\text { from } 58 \% \text { to } 80 \% \text { at } \\
\text { the end of } \\
\text { intervention. }\end{array}$ & Not included \\
\hline
\end{tabular}




\begin{tabular}{|c|c|c|c|c|c|c|}
\hline $\begin{array}{l}\text { Guzmán } \\
\text { C, Baeza } \\
\text { G, Atilano } \\
\text { D, Torres } \\
\text { J, León } \\
\text { O,201730 }\end{array}$ & $\begin{array}{l}\text { Effect of an Educational } \\
\text { Intervention on } \\
\text { Biochemical Parameters } \\
\text { of Diabetic Patients } \\
\text { in an Institutional } \\
\text { Health Service }\end{array}$ & $\begin{array}{l}\text { To know the effect of } \\
\text { an educational } \\
\text { intervention on } \\
\text { biochemical } \\
\text { parameters of diabetic } \\
\text { patients, users of an } \\
\text { institutional health } \\
\text { service. }\end{array}$ & $\begin{array}{l}\text { Quasi- } \\
\text { experimental } \\
\text { with pre-post } \\
\text { evaluation of } \\
\text { intervention. }\end{array}$ & $\begin{array}{l}25 \quad \text { persons } \\
\text { with diabetes } \\
\text { mellitus type } \\
2 .\end{array}$ & $\begin{array}{l}\text { To glucose } p=0.0127, \\
\text { glycosylated } \\
\text { hemoglobin } \\
p=0.0045, \text { cholesterol } \\
p=0.0025, \\
\text { triglycerides } p=0.0114\end{array}$ & Not included \\
\hline $\begin{array}{l}\text { Velasco A, } \\
\text { Ponce E, } \\
\text { Madrigal } \\
\text { H, Magos } \\
G, 2014^{31}\end{array}$ & $\begin{array}{l}\text { Impact of a } \\
\text { Conversational Map as } \\
\text { an Educational Strategy } \\
\text { to Improve the } \\
\text { Metabolic Control of } \\
\text { Patients with Diabetes } \\
\text { mellitus type 2 }\end{array}$ & $\begin{array}{l}\text { To evaluate the impact } \\
\text { of a conversational } \\
\text { map about Diabetes } \\
\text { mellitus type } 2(\mathrm{dm} 2) \text {. }\end{array}$ & $\begin{array}{l}\text { Quasi- } \\
\text { experimental, } \\
\text { assessment pre- } \\
\text { post } \\
3 \text { month span. }\end{array}$ & $\begin{array}{l}30 \text { adults with } \\
\text { diabetes } \\
\text { mellitus type } 2\end{array}$ & 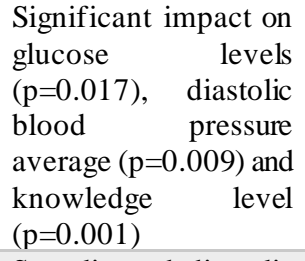 & Not included \\
\hline $\begin{array}{l}\text { Hernández } \\
I, 2018^{24}\end{array}$ & $\begin{array}{l}\text { Effectiveness of } \\
\text { medical therapy and } \\
\text { Diabetes education as a } \\
\text { multimedia program on } \\
\text { Patients with Diabetes } \\
\text { Type } 2 \text { from First Level } \\
\text { attention. }\end{array}$ & $\begin{array}{l}\text { To evaluate the } \\
\text { effectiveness of } \\
\text { medical and } \\
\text { nutritional therapy by } \\
\text { adding a multimedia } \\
\text { educational program, } \\
\text { versus usual medical } \\
\text { care in patients with } \\
\text { type } 2 \text { diabetes } \\
\text { mellitus. }\end{array}$ & $\begin{array}{l}\text { Randomized } \\
\text { clinical trial } \\
\text { with two } \\
\text { intervention } \\
\text { groups and one } \\
\text { control group. }\end{array}$ & $\begin{array}{l}90 \quad \text { patients } \\
\text { with diabetes } \\
\text { mellitus type } 2\end{array}$ & $\begin{array}{l}\text { Systolic and diastolic } \\
\text { blood pressure on } \\
\text { therapy group and } \\
\text { multimedia education } \\
\mathrm{p}<0.05\end{array}$ & Not included \\
\hline $\begin{array}{c}\text { Vargas A, } \\
\text { González } \\
\text { A, Aguilar } \\
\text { M, } \\
\text { Moreno } \\
\&, 2010^{14}\end{array}$ & $\begin{array}{l}\text { Comparative study of } \\
\text { the impact of an } \\
\text { educational strategy } \\
\text { about knowledge level } \\
\text { and quality of life in } \\
\text { patients with diabetes } \\
\text { mellitus type } 2\end{array}$ & $\begin{array}{l}\text { To determine the } \\
\text { biochemical } \\
\text { parameters, } \\
\text { the level of knowledge } \\
\text { and the quality of life } \\
\text { in group of } \\
\text { patients with diabetes } \\
\text { mellitus } 2 \text { who } \\
\text { attended CMD «Dr. } \\
\text { Ignacio Chávez», } \\
\text { ISSSTE, after a year } \\
\text { of having taken the } \\
\text { "course for diabetic } \\
\text { people" r«Course for } \\
\text { diabetic patients» and } \\
\text { to compare } \\
\text { and compare them } \\
\text { with those observed } \\
\text { after six months of } \\
\text { being studied. }\end{array}$ & $\begin{array}{l}\text { Quasi- } \\
\text { experimental } \\
\text { and clinical }\end{array}$ & $\begin{array}{l}21 \text { patients for } \\
\text { one } \\
\text { experimental } \\
\text { group and } 17 \\
\text { for one control } \\
\text { group }\end{array}$ & $\begin{array}{l}\text { In intervention group: } \\
\text { Serum glucose } \\
p=0.004, \text { quality of } \\
\text { life with } p=0.01 \text { and } \\
\text { knowledge } p=0.00\end{array}$ & Not included \\
\hline
\end{tabular}

Source: Own elaboration.

Besides, studies considered several didactic methods to take information from people with diabetes. All of them focused on a constructivist pedagogical model and tested patient`s creativity and participation. At the end, the target was a learning improvement and its implementation in daily life.

On the other hand, the information is addressed to the patient, because they are directly affected by their own lifestyle. Both health professional and the family of a patient with diabetes must accept their responsibility to support them. For this, it is necessary to include the patient's family. ${ }^{32}$
Accordingly, the family members should be actively involved, and attend all the interventions. As Pérez Rodríguez et al. ${ }^{17}$ mentioned, family share as many risk factors as the patients who must be cared based on health promotion and prevention.

Educational interventions about diabetes have a positive impact on adopting healthy lifestyles, ${ }^{37}$ on improving biochemical results and somatometric measures. ${ }^{34}$ 
An important part of educational interventions is to assist people. It has been proven that there is a clear genderdifference. Women attend in greater number than men. The study of Ávila Domínguez ${ }^{25}$ concluded that the interest of health care is not evident in males, since their participation was very low. Also, persuading people to attend educational sessions is another crucial finding of the studies; as Velasco refers, it was a challenge to motivate people to attend and engage in educational sessions.

In Mexico, the management of educational content improves the effectiveness of educational sessions. It is an opportunity to rethink strategies and adapt them to the sociocultural context, allowing the person to focus attention on friendly content and using technology that is possibly unknown. In this regard, it could be useful to consider the engaging of multimedia strategies to provide information to people who suffer from diabetes, because in the short term they can improve some biochemical parameters. ${ }^{24}$ Also, the use of conversational maps as a teaching tool allows participants to interact and actively engage to improve their health conditions, since it is a tool easy to use, inexpensive and attractive. ${ }^{31}$

Most studies showed a problem about continuity of educational interventions. It is a problem because it works to carry out planning, diagnosis, pilot testing, perform the procedure, get the results, analyze them. Studies probably deliver results to the study population and also to health agencies or institutions where they manage their disease.

A consequence of that is a waste of research production. Only interventions that have continuity are carried out as part of the Mutual Aid Groups for Chronic Diseases (GAM-EC), however, it is not likely to innovate the way sessions are conducted, or the inclusion of different ideas from interventions made by other health professionals. All of this could cause results focused on these studies were the same or with minor factors. As it can be seen, when a lack of continuity occurs, it would be observed that people return to a state of bad control, so, at the end of educational sessions, participants improve in terms of disease control, but once they stop attendance, they return to their same unhealthy life styles, which conditioned them to a bad control.

Therefore, it is an opportunity for such future interventions and for people with diabetes mellitus type 2, to foster innovational medical equipment and a multidisciplinary ${ }^{35}$ team responsible for providing continuity in health units. Important find ings must be taken into account that benefit and enrich the planning, organization and participation in educational sessions since they are probably a start to improve this education ${ }^{33}$ issue as part of the comprehensive treatment of a person who has a chronic illness such as diabetes mellitus type $2 .^{14,25,36}$

\section{CONCLUSION}

Education in people with diabetes mellitus (DM) in Mexico is an issue that needs to be strengthened, an issue that requires commitment and efforts of the health sector, health professionals and especially, the whole society. When interventions are made to educate people living with DM, then favorable results improve disease control, but also arise not favorable results like low attendance, lack of commitment and above all, the lack of continuity in health care. With this, the impact that several studies and efforts have had on the health sector in Mexico, is not reflected in the disease control for people with DM, as it was represented at the beginning of this work, with raw data about mortality, morbidity, complications and economic impact for the management of the condition.

\section{REFERENCES}

1. Jamison, DT, Nugent R, Gelband H, Horton S, Jha P, Laxminarayan R, Mock CN. Prioridades para el control de enfermedades. 3a ed. Washington, DC: Banco Mundial; 2018: 1-44.

2. Valadez-Figueroa IA, Aldrete-Rodríguez MG, Alfaro-Alfaro N. Influencia de la familia en el control metabólico del paciente diabético tipo II. Salud Públ. Mex.1993;35(5):1-8.

3. Interial Guzmán MG, Campillo Toledano C, Aguilar Benítez I. Análisis comparativo del programa de educación en diabetes mellitus de México y Cuba.Rev. Cuid. 2013;4(1):516-22.

4. Secretaría de Salud. El impacto de las políticas públicas sobre diabetes mellitus. Available from: https://www.gob.mx/salud/es/documentos/elimpacto-de-las-politicas-publicas-sobre-diabetesmellitus?state=published [Accessed 1 february 2020].

5. Mejía X. Padece diabetes $15.8 \%$ en México; el primer lugar en la OCDE. Available from: https://www.excelsior.com.mx/nacional/2017/11/10/1200370 [Accessed 2 february 2020].

6. Secretaría de Salud, Instituto Nacional de Salud Pública. Encuesta Nacionalde Salud y Nutrición de Medio Camino 2016 (ENSANUT MC 2016). Informe final de resultados. Available from: http://fmdiabetes.org/wp-content/uploads/2017/04/ENSANUT2016mc.pdf [Accessed 2 february 2020].

7. Instituto Nacional de Estadística y Geografía. Mortalidad General. Available from: https://www.inegi.org.mx/sistemas/olap/Proyectos/bd/continuas/mortal idad/Morta lidadGeneral.asp [Accessed 7 march 2019].

8. International Diabetes Federation (IDF). Diabetes Voice Perspectivas Globales sobre la Diabetes. Diab. Voi. 2017 ;62(1):1-30.

9. International Diabetes Federation (IDF). IDF DIABETES ATLAS. Available from: http://fmdiabetes.org/atlas-idf-2017/ [Accessed 2 february 2020].

10. Jasso-Huamán LE, Villena-Pacheco A, Guevara-Linares X. Control metabólico en pacientes diabéticos a mbula torios de un hospital general. Rev. Med. Hered. 2015;26(1):167-72.

11. Organización Mundialde la Salud(OMS). Las 10 principales causas de defunción. Available from: https://www.who.int/es/news-room/factsheets/detail/the-top-10-causes-of-death. [Accessed 1 february 2020].

12. Secretaría de Salud. Norma Oficial Mexicana NOM-015-SSA2-1994, Para la prevención, tratamiento y controlde la diabetes. Available from: http://www.salud.gob.mx/unidades/cdi/nom/m015ssa24.html [Accessed 7 march 2020]. 
13. International Diabetes Federation (IDF). DAWN 2: Evaluando el apoyo psicosocial para las personas con diabetes y sus familias. Diab. Voi. 2013;58Número Especial(s2):1-62.

14. Vargas Ibáñez A, González Pedraza A, Aguilar Palafox MI, Moreno Castillo YC. Estudio comparativo del impacto de una estrategia educativa sobre el nivel de conocimientos y la calidad de vida en pacientes con diabetes mellitus tipo 2. Rev. Fac. Med. 2010;53(2):60-8.

15. Rivera Vázquez $P$, Hernández Villanueva C, Carbajal Mata FE, Ma ldonado Guzmán G. Funciona lidad Familiar y Control Glicemico en Adultos Diabeticos Tipo2 en una Comunidad Rural de Tamaulias, México. Rev. Car. Cienc. Sos. 2016.

16. Lima Santos A, Silva Marcon S. How people with diabetes evaluate participation of their family in their health care. Invest. Educ. Enferm. 2014;32(2):260-9.

17. Pérez Rodríguez A, Berenguer Gouarnaluses M, Inclán Acosta A, Dacal Bell Y, Enrique Perea D. Capacitación sobre diabetes mellitus a familiares de personas afectadas de un consejo popular. MEDISAN. 2018;22(3):287-94.

18. Alulima Salazar SM. La familia como factor desencadenante de descompensación en la salud integral y la adherencia al tratamiento de los pacientes con diabetes mellitus tipo II que asisten al servicio de clínica del hospital general Isidro Ayora de la ciudad de Loja, periodo. 2015-2016. Loja: Universidad Nacional de Loja; 2016.

19. López Ramón C, Ávalos-García MI. Diabetes Mellitus tipo 2: Barreras y perspectivas en el control del paciente. Horiz. Sa nit. 2013;12(2):63-9.

20. Casanova Moreno M de la C, Bayarre Vea HD, Navarro Despaigne DA, Sanabria Ramos G, Trasancos Delgado M. Assessment of Diabetes Education Program in the Elderly at Hermanos Cruz Polyclinic. RCMGI. 2013;30(4):296-307.

21. Chapman Sánchez M, García Almaguer R, Caballero González G, Paneque Caballero Y, Sablón Mariño A. Effectiveness of educational intervention in the knowledge of the diabetic patient about self-care. Rev. Cubana Enfermer. 2016;32(1):49-59.

22. Beléndez Vázquez M, Lorente Armendáriz I, Ma deruelo Labrador M. Estrés emocional y calidad de vida en personas con diabetes y sus familiares. Gac. Sanit. 2015;29(4):300-3.

23. Shawon MS, Hossain FB, Adhikary G, Das Gupta R, Hashan MR, Rabbi MF, Ahsan GU. Attitude towards diabetes and social and family support among type 2 diabetes patients attending a tertiary-care hospital in Bangladesh: A cross-sectional study. BMC Res. Notes. 2016; 9:286.

24. Hernández Lira I. Efectividad de la Terapia Médica y la Educación en Diabetes como un Programa Multimedia en Pacientes con Diabetes Tipo 2 del Primer Nivel de Atención. México: Universidad Nacional Autónoma de México; 2018.

25. Ávila Domínguez R. La educación en diabetes con enfoque intercultural desde la Teoría de la Modificabilidad Cognitiva- Programa de Enriquecimiento Instrumental [PEI]. Pachuca: Universidad Autónoma del Estado de Hidalgo; 2018.

26. Hernández Sánchez NS. Eficacia de la Educación en Diabetes en los Parámetros Clínicos y Bioquímicos en Pacientes Portadores de Diabetes Mellitus que Concluyeron un Año de Capacitación en el Grupo de DiabetIMSS en el HGZ con UMF1, Pachuca, Hidalgo. México: Universidad Nacional Autónoma de México; 2018.

27. Velasco Limón E. Efectividad de una intervención educativa en el nivel de conocimiento de pacientes con Diabetes mellitus tipo 2 de Unidades de Especialidades Médicas de Enfermedades Crónicas del Distrito Federal. México: Instituto Nacional de Salud Pública; 2016.

28. Hernández P, Maldonado Muñiz G, Trejo García CÁ, López B, CanoEstrada A. Efecto de la educación para la salud en pacientes con diabetes mellitus tipo 2 del centro de salud de Atotonilco de Tula, Hidalgo, México. Rev. Fac. Cienc. Salud UDES. 2015;2(2):110-6.

29. Pichardo-Hernández JH, Elizaldi-Lozano NE. Alcances de una estrategia educativa en pacientes diabéticos de una unidad de medicina familiar. Aten. Fam. 2015;22(4):108-10.
30. Guzmán-Priego CG, Baeza-Flores G del C, Atilano-Jiménez D, TorresLeón JA, León-Mondra gón Ode J. Efecto de una intervención educa tiva sobre los parámetros bioquímicos de pacientes diabéticos de un servicio médico institucional. Aten. Fam. 2017;24(2):82-6.

31. Velasco-Casillas A, Ponce-Rosas ER, Madrigal-de-León HG, MagosArenas G. Impacto de un mapa conversacional como estrategia educativa para mejorar el control metabólico de pacientes con Diabetes mellitus tipo 2. Aten. Fam. 2014;21(2):42-6.

32. Fort MP, Castro M, Peña L, López Hernández SH, Arreola Camacho G, Ramírez-Sea M, Martínez H. Opportunities for involving men and families in chronic disease management: a qualitative study from Chiapas, Mexico. BMC Public Health. 2015; 15:1019.

33. Villarreal-Hernández LS, Romo-Martínez JE. Educational status and life expectancy in patients with chronic non-communicable diseases. Rev. Med. Inst. Mex. Seguro Soc. 2014;52(3): 316-21.

34. Peña-Purcell NC, Boggess MM, Jimenez N. An empowerment-based diabetes self-management education program for Hispanic/Latinos: a quasi-experimentalpilot study. Diabetes Educ. 2011;37(6): 770-9.

35. Whittemore R, Vilar-Compte M, Cerda S, Marron D, Conover R, Delvy R, Lozano-Marrufo A, Pérez-Escamilla R. Challenges to diabetes selfmanagement for adults with type 2 diabetes in low-resource settings in Mexico City: a qualitative descriptive study. Int. J. Equity Health. 2019;18(1): 133 .

36. Pacheco LS, Hernández-Ontiveros DA, Iniguez-Stevens E, Brodine S, Garfein RS, Santibañez M, Fraga MA. Prevalence and correlates of diabetes and metabolic syndrome in a rural indigenous community in Baja California, Mexico. BMC Public Health. 2018;18(1): 1397.

37. Fort MP, Murillo S, López E, Dengo AL, Alvarado-Molina N, Beausset I, Castro M, Peña L, Ramírez-Zea M, Martínez H. Impact evaluation of a healthy lifestyle intervention to reduce cardiovascular disease risk in health centers in San José, Costa Rica and Chiapas, Mexico. BMC Health Serv. Res. 2015;15: 577. 